This article was downloaded by: [New York University]

On: 06 February 2015, At: 19:24

Publisher: Routledge

Informa Ltd Registered in England and Wales Registered Number: 1072954

Registered office: Mortimer House, 37-41 Mortimer Street, London W1T

3J H, UK

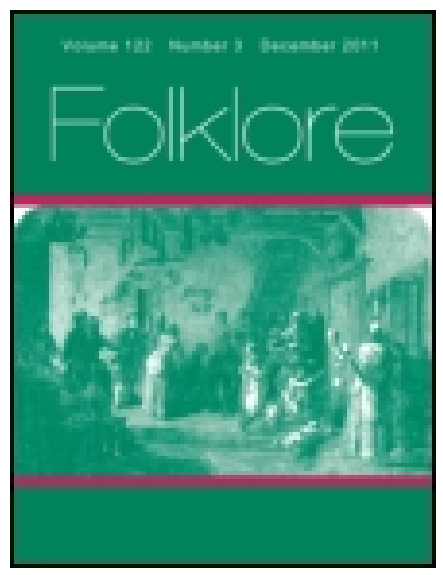

\title{
Folklore
}

Publication details, including instructions for authors and subscription information:

http:// www. tandfonline.com/loi/ rfol20

\section{Notes from South Nigeria.}

R. E. Dennett

Published online: 14 Feb 2012.

To cite this article: R. E. Dennett (1905) Notes from South Nigeria., Folklore, 16:4, 434-439, DOI: 10.1080/0015587X.1905.9719977

To link to this article: http:// dx. doi. org/ 10.1080/0015587X.1905.9719977

\section{PLEASE SCROLL DOWN FOR ARTICLE}

Taylor \& Francis makes every effort to ensure the accuracy of all the information (the "Content") contained in the publications on our platform. However, Taylor \& Francis, our agents, and our licensors make no representations or warranties whatsoever as to the accuracy, completeness, or suitability for any purpose of the Content. Any opinions and views expressed in this publication are the opinions and views of the authors, and are not the views of or endorsed by Taylor \& Francis. The accuracy of the Content should not be relied upon and should be independently verified with primary sources of information. Taylor and Francis shall not be liable for any losses, actions, claims, proceedings, demands, costs, expenses, damages, and other liabilities whatsoever or howsoever caused arising directly or indirectly in connection with, in relation to or arising out of the use of the Content.

This article may be used for research, teaching, and private study purposes. Any substantial or systematic reproduction, redistribution, reselling, loan, sub-licensing, systematic supply, or distribution in any form to anyone is 
expressly forbidden. Terms $\&$ Conditions of access and use can be found at http://www.tandfonline.com/page/terms-and-conditions 
COLLECTANEA.

\author{
NOTES TROM SOUTH Nigeria. \\ (Ante, p. 242.) \\ I. Making Father (Eximi).1
}

(Extract from my Journal). We purposed crossing the river Osseomo or Awreomo on the morrow (the 22nd April, 1903), so we sent a boy on ahead to say that we were coming and would cross the river in the morning.

Soon after our arrival at Ogugu's town he came to welcome us, accompanied by one or two Benin City chiefs and their followers. He told us that he had intended "making father" that evening, but that as we had come and the festivities might annoy us, he would put the feast off until we had gone. We thanked him for his welcome and assured him that we should very much like to be present while he was "making father," and prayed him to proceed with his festival just as if we were not present. He seemed pleased to be honoured by our presence, and ordered his people to bring us wood, fire, and water, and food for ourselves and our boys.

Shortly after dark crowds of people bearing lamps and torches came together in front of Ogugu's residence. The cloistered wall through which one had to pass to obtain an entrance into his house contained several altars, and as we lay on our camp beds in the rest-house opposite, we gazed through the door and window at what was going on before us.

There stood Ogugu before one of the altars dressed in what

1 Cf. Miss Kingsley, Wast African Strudies, p. 146. 
appeared to be a red hat and gown, a glowing figure, the lurid light of many torches falling on him. Then a goat was held up so that he might sever its head from its body and sprinkle its blood upon the altar. Six goats were killed, and all the altars within and without the house sprinkled with their blood, and all this was done in comparative quiet. Then Ogugu, a Nabori holding up one of his arms and followed by his courtiers, danced before his people. Then followed the three great dances called Okele, Ugulu or Sakwoadi, and Ohogo, which I will describe later on. We saw but little of these dances that night, but from the noise that took place the natives appeared to have appreciated them; and then for a time all was quiet. Soon, however, bands of people singing and bearing lamps and torches wended their way in Indian file round about and into Ogugu's residence; no sooner bad one emerged than another seemed to take its place, and their songs as they approached and wandered about the place and finalls departed were weird and beautiful. Some sang softly in falsetto, and some sang songs that reminded one of old Gregorian chants. This went on all night. In the early morning Ogugu, preceded by a band of drummers and players on beaded gourds, came out of his house followed by many hundreds of people. Immediately in front of him was a man bearing a dish of cowries ( $\left.I_{\mathrm{g} O}\right)$, and just behind him was his umbrella bearer and his courtiers. Under the shade of this umbrella Ogigu crushed the cones of chalk (Orhue) and sprinkled the dust upon the cowries. Thus the procession passed us on its way down the grassy glade which led to the Benin City road. The band waited for the procession just where the glade is divided by Kolo trees from the village, while it proceeded to the "juju" place to salute the great father who, in the spirit, is still in Benin City, but who, 2s Overami, the late king of Benin, is in reality a prisoner in Old Calabar. On the return of the procession the band joined it, and Ogugu scattered the cowries right and left to the boys and girls who scrambled for them.

Thus did Ogigu celebrate the anniversary of the death of his father.

Then he came to greet us as we sat in front of the rest-house, 
and asked us if we would like to see the dances more distinctly, as he was afraid that we had seen very little of them the night before: we thanked him and said yes.

The first dance, called Ugulu or Sakwadi, was danced by one man only. He turned circles, keeping perfect time to the band of beaded calabashes and drums. The second, Okele, was rather more interesting, as it was danced by two men; one had a fan in his hand, and the other had his hands clasped in front of him. The man with the fan went through certain steps which the man with the hands clasped had to copy exactly; when he failed another took his place. The third dance was called Obogo, and was most remarkable. Fifteen men, three with native bells and the rest with beaded calabashes, took part in it They were scantily dressed and had bells and rattling seeds round their arms and ankles. A man with a bell (evidently their conductor), with one with a beaded calabash, were surrounded by the other thirteen in a perfect circle At a signal from their conductor the thirteen ran round in a circle, while all beat their calabashes and bells; suddenly they stopped, turned towards each other in couples and saluted each other; at a signal they then started of again, changing their step as it pleased their conductor, who seemed to have perfect control over their movements. Then at a signal all danced inwards towards the centre of the circle, and crowded themselves over their now crouching conductor and his companion. At a beat of his bell all withdrew and continued dancing in a circle. The many and complicated steps, all perfectly accomplished, placed this dance a long way above the general average native dance, and we were more than astonished to find how perfectly trained these dancers were. We were told that in the olden days the slightest error in public in such a dance was punished by death.

\section{A Ladies' Dance.}

On the and August, 1903, the chief, Obaseki, gave a dance to which he invited the officers then present in Benin City. This dance was given in one of the rooms in the chief's bouse. The room was square in shape, the roof sloping inwards towards the centre which was open, forming womething between a Roman 
pluvium and a Spanish patio, some 15 or 20 feet square. On two sides were recesses, in one of which the chief's wives were crowded, and it was on the mud platform in front of this recess that the dancing took place.

Some of the wives played the drums, while others beat the beaded calabashes and sang the choruses to the songs of the different ladies who from time to time got up and danced and sang. Each lady was evidently famous for some particular song and step, but we preferred one that reminded us rather of one of our own round dances, danced to a song full of her husband's praise.

\section{Secret Societies.}

The object that most of the Secret Societies round about Benin seem to have at heart is to check the despotism of the rulers of the people, but often the ruler himself becomes 2 member of the Society and soon its leader thus secures its services in furthering his own despotic ideas.

The Bini call their Society Igwomori, and it is eaid that while still a prince the late king, Overami, became a member of it. The first crime this Society committed on the death of king Adolo and crowning of Overami, and at the latter's suggestion, was to execute all the late Adolo's councillors. Overami then placed many of the Igwomori, many of whom were sons of the lately executed councillors, in their father's place.

The Secret Society of the Ishan people played a great part in defending the Benin City chief, Abohon, and other refugees after the British had taken Benin City in 1897-8.

There are Secret Societies at Owo and Akwe.

The Sobo Society is called Otrada, that at Ifton, Otu, while we have only just had a sad experience of the influence of the Ekemeku, or the Silent Ones, in the hinterland of Asaba.

In an interesting article, dated May 13, 1904, in the West African Mail, Mr. Hughes, an earnest student of African customs, writes :

"The Ekemeku Society has for long been in existence. The aim and idea of its establishment was :

18t. To settle any tribal differences amicably. 
and. To uphold the law and institution of their countries according to rights of usage.

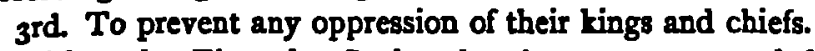

Of late the Ekemeku Society has become composed for the most part of the younger and more lawless elements, who hold their meetings at night, who work by secret methods, and who are a continual source of terror to the more peaceful natives, whom they compel by threats of death to contribute to their Society."

\section{Marriage and Birth Customs.}

There appear to be two kinds of marriages among the Bini.

Among the upper classes the children are betrothed by their parents from infancy. The present may be a nominal one, such as four kolas, three cowries and some palm wine, or it may be more.

The man is supposed to keep on giving the child betrothed to him presents until she is grown up; he also makes her parents gifts. The seduction of such a betrothed girl is heavily punished. On the other hand, among the poor, the girl is not necessarily betrothed, and a man may seduce her without legal punishment.

The man may refuse to marry his betrothed, and then he has the right to give her in marriage to anyone, unless she is of noble family, when she can only be given to a free man.

The girl may not refuse to marry the man to whom she is betrothed or his chosen representative. But the father may at any time refuse to give his daughter to her betrothed, but he has to refund to him all the presents the would-be husband has given to her and her parents.

When his wife conceives, the husband gives her a cock to sacrifice.

The son marries his deceased father's wives.

After the birth of a child, the father gives the mother another name. The child also will give her mother a name, a friend will also name her; and so one often hears a person spoken of by two or three names.

Very few women in this country are true to their husbands, 
most of them having at least one lover. When a child is born, the woman does not declare who its father is until her husband is dead. Many women live openly with their lovers; the great majority of cases in court are for return of a wife, and many women prefer to go to prison than to return to their legal husbands.

Often on the roads one passes a small tree planted by the side of the road near which are chalk marks and a mound of earth, cowries, yams and plantains. This tree has been planted in memory of the fact that some woman or other has brought forth a child on that spot.

R. E. Dennett.

Additions to the Games or Aroyleshire,

(Continued from supra, page 349.)

\section{MINTRACHAN.}

(P. I65, after line 15.)

In Barra the above is called "Biorrachan beag agus Biorrachan mor." It begins with the statement. "Chaidh Biorrachan beag agus Biorrachan mor latha a bhuain cnothan. Mar a bhuinneadh Biorrachan mor dh'itheadh Biorrachan beag.

"Chaidh Biorrachan mor gus a' choille a dh'iamuidh slait gus gabhail air Biorrachan beag a dh'ith na cnothan. Nuair a ruig e 'n coille, etc" (Little Biorrachan and big Biorrachan went one day to gather nuts. As big Biorrachan gathered, little Biorrachan ate. Big Biorrachan went to the wood to seek a switch to thrash little Biorrachan who ate the nuts. When he reached the wood, etc.) With the change of names the narrative was the same as that given from p. 158 , line 18 , to $p$. $16 t$, line 16 , where the "yellow-baired woman "becomes "the woman baking," "a bhean fuinneadh." Biorrachan asks for a bannock; "Cha'n thaigh thu 